\title{
GMR
}

$\underline{\text { Retraction }}$

\section{RETRACTION of "Association between polymorphisms in the XRCC1 gene and the risk of non-small cell lung cancer", by Han JC, Zhang YJ and Li XD - Genet. Mol. Res. 14 (4): 12888-12893 (2015)}

\author{
Genet. Mol. Res. 15 (4): gmr.150462131 \\ Published October 7, 2016 \\ DOI http://dx.doi.org/10.4238/gmr.150462131 \\ Copyright (C) 2016 The Authors. This is an open-access article distributed under the terms of \\ the Creative Commons Attribution ShareAlike (CC BY-SA) 4.0 License.
}

The retracted article is:

Han JC, Zhang YJ and Li XD (2015). Association between polymorphisms in the XRCC1 gene and the risk of non-small cell lung cancer. Genet. Mol. Res. 14: 12888-12893.

The GMR editorial staff was alerted about this article (received on May 3, 2015; accepted on August 18, 2015) published on October 21, 2015 (DOI: 10.4238/2015.October.21.9) that was found to be substantially similar to the publication of "Association of XRCC1 gene polymorphisms with risk of non-small cell lung cancer" (received on January 25, 2015; accepted on March 23, 2015; e-published on April 1, 2015) by Kang et al., published in the International Journal of Clinical Experimental Pathology 8 (4): 4171-4176.

The authors were aware of the Kang et al.'s paper, since they cite it several times in the manuscript published in GMR. Some of the language is similar between the two manuscripts, but what is the most concerning is that several of the tables in the papers are nearly identical. Tables 2 and 3 are exactly identical between the two articles, suggesting that the publication in GMR was plagiarized from the publication in the International Journal of Clinical Experimental Pathology.

The Publisher and Editor decided to retract these articles in accordance with the recommendations of the Committee on Publication Ethics (COPE). After a thorough investigation, 
we have strong reason to believe that the peer review process was failure and, after review and contacting the authors, the editors of Genetics and Molecular Research decided to retract the article. The authors and their institutions were advised of this serious breach of ethics.

\section{Link to original paper}

Genetics and Molecular Research 15 (4): gmr.150462131 